\title{
Substantive conceptual development in preschool science: contemporary issues and future directions
}

Article

Accepted Version

Allen, M. and Kambouri-Danos, M. (2017) Substantive conceptual development in preschool science: contemporary issues and future directions. Early Child Development and Care, 187 (2). pp. 181-191. ISSN 1476-8275 doi:

https://doi.org/10.1080/03004430.2016.1237561 Available at https://centaur.reading.ac.uk/68168/

It is advisable to refer to the publisher's version if you intend to cite from the work. See Guidance on citing.

Published version at: http://dx.doi.org/10.1080/03004430.2016.1237561

To link to this article DOI: http://dx.doi.org/10.1080/03004430.2016.1237561

Publisher: Taylor \& Francis

All outputs in CentAUR are protected by Intellectual Property Rights law, including copyright law. Copyright and IPR is retained by the creators or other copyright holders. Terms and conditions for use of this material are defined in the End User Agreement.

www.reading.ac.uk/centaur 
Central Archive at the University of Reading

Reading's research outputs online 


\title{
Substantive conceptual development in preschool science: contemporary issues and future directions
}

\author{
Michael Allen ${ }^{a}$ and Maria Kambouri-Danos ${ }^{b}$ \\ aKingston University, Kingston upon Thames, UK[AQ1] \\ bUniversity of Reading, Reading, UK
}

CONTACT Michael Allen m.allen@kingston.ac.uk

\section{Introduction}

Between birth and 7-8 years, children quickly mature in a variety of different ways[AQ2] (Doherty \& Hughes, 2009). There is a vast amount of literature concerning this early years child development that deals with how their abilities advance physically, socially, emotionally, cognitively and linguistically' (Johnston, 2005, p. 1). Research in the developmental cognitive domain has been largely conducted by psychologists, not educationalists; one consequence of this being that at present, studies involving preschoolers' science concepts are all but absent from the four most prominent journals in the field of science education. The current article will first consider some of this developmental psychology research and how it can be relevant to science educators, and then later discuss potential ways forward that may help increase the profile of early years science in the literature.

Classic theorists have presented models of how children's cognitive abilities progress throughout childhood, the best known of which is probably Piaget's stages of cognitive development (Piaget, 1972). For Piaget, a child's view of the world and the way it works is different in nature as well as degree of sophistication from that of an adult (Driver, Asoko, Leach, Mortimer, \& Scott, 1994). He proposed that there are periods during childhood that each individual passes through, and each period, or 'stage', is characterised by particular qualities of thinking (Atherton, 2009). Each stage is markedly different from the others and children pass from one stage to the next in a predictable way, once an approximate age is reached. For instance, the concrete operational stage (7-11 years) is concerned with thinking about perceptual attributes of cases, while during the formal operational stage (11-16), abstract thought is developed (Atherton, 2009; Piaget, 1972).

Contemporaries of Piaget, Bruner and colleagues formulated their own theory of child development that similarly delineated a predictable sequence of periods, with thinking evolving from being image-based to symbol-based (Bruner, Goodnow, \& Austin, 1967). Vygotsky also shared many of Piaget's assumptions about the way that children learn; however, he highlighted the importance of the social context of learning (MooneyGarhart Mooney, C, 2000. Theories of Childhood: , 
П2000). In Vygotsky's theory, both teachers and older or more experienced children play a very important role in the children's learning, opposing Piaget's cognitive theory in which the teacher plays a limited role (Smidt, 2009; Vygotsky, $\underline{1978}$.

The above and other classic theorists had significant and lasting effects on education, particularly Piaget, whose stage model was readily accepted in a variety of educational contexts, with countless programmes and curricula having since been written based on the Piagetian view (Mooney, 2000). However, in spite of Piaget's early, enduring popularity, nearly all modern cognitive psychologists now refute his stage model. Research has since demonstrated that there is little evidence for a stepwise progression of phases that is highly dependent on age (Doherty \& Hughes, 2009). Classic discontinuous models of stepwise cognitive development often view children as solitary learners, failing to take into account the possible effects of social influences. For example, Jahoda (1983)[AQ4] found that Zimbabwean nine-year-olds who worked in the family business were able to understand the abstract concept of profit, something that British children were not able to grasp until 11-12 years. Children raised in different cultures will construct concepts that reflect not only their current degree of cognitive development but also the norms and practices of those cultures. In the same vein, Vygotsky (1978) explained how in diverse cultures there are differences in social interactions which lead to a cultural variance in the acquisition of cognitive abilities. As a result, classic stepwise theories may give the impression that the development of cognitive abilities is predetermined, or 'hardwired', with step changes occurring automatically when triggered by chronological age. Instead, modern constructivist theories of development assume that a child's abilities are experience-mediated and not age-mediated - that is, concepts build up steadily over a period of time and depend wholly on the life experiences of each child. Therefore, a child's formal education, interactions with parents and peers and contact with entertainment and other media are crucial factors for development. These views correspond with those of constructivist science educators such as Posner, Strike, Hewson, and Gertzog (1982)[AQ5] who state that previous constructions are a major governing influence on new learning (see later).

\section{Conceptual development in the early years}

Historically, preschoolers' conceptions of science were not investigable, as it was perceived that children could not understand scientific phenomena (De Kock, 2005). However, brain development research proves that a young brain develops rapidly neurologically during the first years of life (Doidge, 2007). Within the first 18 weeks of life, neurogenesis (production of neurons, i.e. nerve cells) occurs at an average rate of 500,000 per minute (Eliot, 1999[AQ6]). Using glial cells to guide them, these neurons migrate to their genetically preordained place, forming neurological connections which will be used to make sense of experiences (Eliot, 1999; Zull, 2002). Nowadays, research has begun to accept that the learning of concepts and conceptual change is in the centre of young children's learning of science (Nussbaum, 1989).

Scientific concepts can be seen as 'those ideas or general notions of the common attributes of objects or events that help us to understand the natural and physical world around us' (Bradley, 1996, p. 43). Vygotsky (1986) defines 'scientific concepts' as those concepts which are introduced in formal education (e.g. by a teacher), whereas he sees 'spontaneous concepts' as those which are acquired by children's outside contexts in which explicit instruction is in place. He also refers to the concept of 'mediation' which leads to the development of a 'non-deterministic account in which the individual acts upon and is acted upon by social, cultural and historical factors' (Daniel, 2002, p. 14). Alternatively, Johnston (2005) divided children's concepts into three different categories: 'factual knowledge' refers to concepts developed through first-hand experiences or secondary sources (television and books), 'fictional knowledge or myths' refers to secondary sources of knowledge (tales and stories), whereas 'inferred knowledge' is about those concepts that result from an interaction between children's practical experiences and the existing concepts that they hold. The last category may lead to concepts that are not completely accurate and can have a profound influence on further conceptual development (Johnston, 2005).

In all cases, scientific concepts are formed as a result of previous experiences and they can affect children's learning of science (Eaton, Anderson, \& Smith, 1984). The main avenue for young children's scientific learning development is the information shared within their environment including, but not limited to, verbal interactions, skills demonstration, television, books, museum visits and, of course, play (Bradley, 1996; Hollins, Whitby, Lander, Parson, \& Williams, 2001; De Kock, 2005; McGinn, 1998[AQ7]). For instance, when children use a see-saw, they experience that by pushing up one end of the see-saw, the other end will go down, even if they may not be able to verbalise their understanding in terms of physics. Even bath time can be a stimulus for children since while playing with bath toys, they can experience sinking and floating (when they push bath toys under the water some of them will sink and some others will come back up).

As a result, preschoolers' physical and social experiences explorations support the development of their scientific understanding (Johnston, 2005). Children use their everyday experience to develop their scientific concepts which they then divide into smaller 'sub-concepts' to help make them less abstract and more specific and restrictive (Bradley, 1996). The concepts and sub-concepts developed are then employed to identify patterns and relationships between the way things are made and the way they behave, whether it is the different forms that water can exist (liquid, gas or solid) or why and how a shadow appears.

These firm cognitive concepts are very closely linked to children's personal experiences, which can be wide ranging and diverse even if they are sometimes limited in understanding (Johnston, 2005). This can have a remarkable influence on the children's subsequent cognitive development since the information capability of each child can set limits on the complexity of concepts that the child is able to cope with (Kambouri, 2015). Consequently, Guest (2003[AQ8]) highlights that conceptual development is not solely about becoming faster or fuller of knowledge, since the qualitative changes taking place when children are processing new information are equally (or even more) important than the speed of the process or the quantity of the new knowledge acquired.

\section{An overview of cognitive research}

Despite the wealth of research in the developmental psychology genre, there is currently a dearth of studies that have investigated the nature of preschoolers' substantive science concepts - that is to say, those scientific ideas which are listed within programmes or syllabi such as the English National Curriculum (Department for Education, 2013). Substantive concepts tend to focus on science facts and understanding, and exclude process skills that fall within the category of scientific enquiry. Treagust (1988) adds that most researchers followed Piaget's approach to probing children's ideas, using interviews.

For example, Osborne and Cosgrove (1983[AQ9]) investigated children's ideas in relation to ice melting, water boiling, evaporating and condensing. These events were shown to children, during individual interviews, requiring the children to discuss and explain the phenomenon taking place (Osborne and Cosgrove, 1983). Similarly, Eaton et al. (1984) looked into children's scientific concepts in relation to light, using observations and audio-recorded lessons (Eaton et al., 1984). The results indicate that children had difficulties in learning about light because neither their text nor their teachers dealt with their students' prior knowledge and misconceptions adequately. 
A few years later, Gelman (1990) asked 4-5-year-olds what kinds of things were inside the bodies of animals (specifically people, elephants, cats, mice and birds). Common to all of the animals were blood, bones and heart, and individual animals were thought to have characteristic things inside them, with elephants containing water, mice, cheese and birds, feathers. In a study about how preschoolers consider kinship and family, children tended to attribute the same biological qualities to animals that they had been told were related to each other in a familial way, even though they looked different (Springer, 1992).

$\mathrm{Au}($ 1994) e[AQ10]xplored some fundamental chemistry ideas of 3-5-year-olds, reporting that they were able to appreciate concepts of conservation of matter, including the understanding that a smaller piece taken from a larger chunk of material possesses the same properties as that larger chunk. Palmer (1995) used semi-structured interviews to identify young children's (3-4-year-olds) ideas and understanding of waste management and Kalish (1996) looked at 3-5-year-olds' ideas about the causes of illness, finding that children understood that germs can be the cause of disease but tended to undergeneralise, attributing other causes to diseases that were actually germ-mediated and involved contagion or contamination.

As a result, most research examples include ideas about how light or electricity travels, how water changes []states, where in the body food is digested and what we can do to a material to make it permanently change into something else. This scarcity of relevant work means that preschool science conceptual research remains a rich vein for exploitation by education researchers. Findings from the psychological literature tend to focus on the measurement of children's reasoning faculties, with none of the clear links to teaching or pedagogy that is usually found in education articles.

There has been more research on preschoolers' substantive concepts in the science education genre, particularly recently, with these studies having more relevance to the science curricula taught in schools. For instance, Ravanis and Bagakis (1998) implemented a teaching intervention aiming to identify and change preschoolers' mental representations of water's gasification. The[AQ11] sample consisted of 49 preschool children who were randomly selected and the researchers used a pre-test and a post-test, one month before and one month after the intervention, to establish children's ideas on an individual level. The tests asked for children to predict what would happen during an experiment demonstration on gasification as well as for their comments on a number of pictures shown to them representing the same phenomenon (Ravanis \& Bagakis, 1998). The study's results indicate that children were not able to predict the phenomenon (during the pre-test) while children's answers were evidently [leffected by their individual experiences. Some children gave sufficient answers in relations to 'where the water goes' during gasification, whereas some others made hypotheses and gave answers affected from the experimental apparatus (e.g. into the bottle, into the desk) (Ravanis \& Bagakis, 1998).

Valanides, Gritsi, Kampeza, and Ravanis (2000) interviewed 33 preschool children, using semi-structured interviews, aiming to identify and change their concepts of the day/night cycle. The children were randomly selected from an urban kindergarten of a mixed socio-economic status and none of them had previously received any formal or informal instruction concerning the respective topics. A teaching intervention was designed and implemented, aiming to teach preschoolers about the Sun and the Earth and the day/night cycle. The intervention was delivered by the researchers to small groups of children (6-7) and lasted for approximately 30 minutes. The effect was evaluated two weeks later using an interview similar to the one used prior to the intervention. Valanides et al. (2000) argue that most children more easily accepted that the Sun and the Earth are different spherical objects, but less easily that endorsed the idea that day and night relate to the Earth's rotation on its axis. The children appeared to struggle with the idea of the Earth moving around the Sun and around its axis at the same time. The results indicate that children are not passive receivers of information and they bring their own views of the world to any teaching learning situation and these views, when not acknowledge, can interfere with their scientific learning (Valanides et al., $\underline{2000})$.

A few years later, Gallegos-Cázares, Flores-Camacho, and Calderón-Canales (2009) were interested in preschoolers' grasp of light concepts. They found that children understood that when mixing paints that different colours can be produced, but some incorrectly deduced that the end colour always depends on which of the starting colours were the 'strongest'. Children also displayed misconceptions concerning shadows, including the ideas that shadows are objects themselves, are reflections of objects or have to be the same colour as the object. Similarly, Windt. Scheuer, and Melle (2014) looked at how science process skills could best be taught to a sample of $2215-6$-year-olds, giving differing degrees of autonomy to children while they conducted experiments. They found that although most children were capable of working autonomously, they learned more science only when they were less autonomous and given clear directions by nursery teachers.

In a study that examined children's ideas of natural phenomena, Saçkes, Flevares, and Trundle (2010) found that although many 4-6-year-olds understood that rain was water, and came from the clouds, some believed clouds bring water, but rain falls from the sky and/or that when rain hits the ground it disappears and ceases to exist. They recommend that a basic understanding of the water cycle would likely help children construct appropriate scientific ideas of natural phenomena such as rainfall. Research into preschool substantive science concepts has hardly ever considered how ideas change over time and how these changes relate to early years cognitive development theory. As discussed, there is a notable absence of this research from the four prestigious science education journals, which may be due to less enthusiastic editors who choose not to publish the material because of a perceived lack of reader-interest, or perhaps a shortage of submissions that reach the required quality.

\section{Misconceptions and conceptual change}

The conceptual change movement is generally considered to have started in earnest with the publication of one of the field's seminal papers by Posner et al. of Cornell University in 1982. Posner et al. argued that changing a learner's current way of thinking about a science theory is not necessary a straightforward matter, as they firstly need to be consciously dissatisfied about that theory as a valid representation. Any new, replacement theory will only be accepted if it is intelligible - is able to be understood; plausible - can solve present problems that the old theory cannot and fruitful - can solve any new problems. Their views were grounded in earlier work by Kuhn (1962, paradigm shifts) and Piaget (1977, cognitive disequilibrium).

This realisation that conceptual change is complex yet potentially achievable within any science topic area by following certain steps led to the explosion of so-called misconception research that began in the early 1980s and is still prevalent today (Allen, 2014). The term 'misconception' is used to refer to the children's conceptions which differ from those generally accepted by the scientific community (Guest, 2003; Kambouri, 2015). In previous research and literature, this term can be also found as 'preconceptions' (Ausubel, 1968[AQ12]; Kambouri, 2012[AQ13]), and 'alternative frameworks' (Driver, 1981 [AQ14]), whereas other authors have also used labels such us 'alternative conceptions', 'intuitive theory', 'non-scientific ideas' and 'children's ideas' (Guest, 2003; Hamza \& Wickman, 2007[AQ15]). What is mostly important though about children's science misconceptions is that they can be an obstacle to children's conceptual development when learning science. Stepans and Kuehn (1995) pointed out that misconceptions can make learning more difficult for children who will straggle to accept, learn and remember. 
a surprising lack of research evidence that has demonstrated this. There is, however, a good number of conceptual change studies that have focused the scientific ideas on older children aged 5-11 years (Allen, 2014). If clear links could be made between this established body of work and what preschoolers are thinking, it would help 'fill in the gaps' and inform theory about how science ideas are first formed, with a view to designing interventions that encourage the construction of acceptable ideas at the preschool level. One of the current authors has suggested that such an approach could be called conceptual creation (Allen, 2015).

\section{The future of science learning}

A recent innovation takes the idea of linking children's developing ideas further by formally recognising that changing science ideas can typically take predictable trajectories throughout a child's schooling (preschooling included) (Allen, 2016). When a child is first taught a particular scientific idea, they do not necessarily leave the classroom with a complete, coherent or even a correct version of that idea (Harlen, 2010). It usually takes time for them to construct a final, finished concept that teachers can regard as scientifically acceptable. This may involve the idea changing several times as a succession of different 'mental drafts' are constructed over time. Each successive version becomes more sophisticated and closer to the scientific version. This string of changing concepts is a learning progression and shows how ideas naturally unfold over time (Plummer \& Krajcik, 2010).

As stated, learning progressions are a relatively recent innovation. They first emerged during the mid-2000s from mathematics education in America and were subsequently included as a key aspect of US curricula within the Next Generation Science Standards (NRC, 2012). The learning progression approach requires teachers to present science ideas as a tightly defined sequence during the teaching of a topic. These sequences are designed to encourage the retention of correct ideas and the rejection of incorrect features by presenting concepts in the precise order that they would naturally appear in children. Part of the rationale for this is to teach a curriculum that is informed by conceptual research, which is in contrast to curricula that have been devised by subject experts in a top-down way, not necessarily linked to the sequence in which children normally construct their changing ideas.

Figure 1 is an example of a learning progression that is focused on the different topics of animals including humans as they are listed by the English National Curriculum (DFE, 2013). The $P$ shows progression of concepts over the ages of $5-11$ years that has used several conceptual research studies as a source. It can be seen that many of the concepts morph over this period into more sophisticated variants, while others remain unchanged. Kambouri $(\underline{2015})$ highlights the importance of acknowledging children's misconceptions when planning and teaching science, and to achieve learning progression, it is necessary to elicit children's ideas prior to delivering the teaching sequence in order for each child's current state of attainment to be located on the LP[AQ16]. prior to delivering the teaching sequence children's ideas. Work can thereafter be differentiated accordingly, with children being supported to reach the next level of the LP. It is important that the process be hierarchical, in that concepts at the lower reaches of the LP should be securely understood before higher concepts are introduced. One perhaps controversial aspect is that it is acceptable for the child to attain 'halfway house' concepts that do not completely reflect correct science. Referring to Figure 1, when learning about the concept of living, young children deciding whether or not something is alive can focus exclusively on whether or not it has eyes. If children are secure with this idea then it should be initially encouraged, but later built upon by introducing processes of life other than the ability to sense, as well as introducing examples of living things that do not possess eyes (notably plants). Although Figure 1 has columns for the typical ages of children, it must not be assumed that only children at a particular age are capable of understanding certain ideas. The word 'typical' is important here, and within the same class of children, individuals will not all be at the same level, some will lay at the upper end of the LP, while others at the lower end.

Figure 1. How learning progresses: animals including humans (adapted from Allen, 2016). 


\begin{tabular}{|c|c|c|c|}
\hline & Typically 5-7 years & Typically 8-9 years & Typically $10-11$ years \\
\hline Concept of living & $\begin{array}{l}\text { Anything with eyes and } \\
\text { moving legs is alive. } \\
\text { Anything capable of self- } \\
\text { directed movement is } \\
\text { alive. } \\
\text { Animals and artefacts are } \\
\text { alive; plants are non- } \\
\text { living. }\end{array}$ & $\begin{array}{l}\text { Anything capable of self- } \\
\text { directed movement is } \\
\text { alive. } \\
\text { Animals and artefacts are } \\
\text { alive; plants are non- } \\
\text { living. }\end{array}$ & $\begin{array}{l}\text { Anything capable of self-directed } \\
\text { movement is alive. } \\
\text { Animals and plants are alive; } \\
\text { artefacts are non-living. }\end{array}$ \\
\hline Animal growth & $\begin{array}{l}\text { Animals need food to } \\
\text { grow; growing takes place } \\
\text { only at particular times } \\
\text { (e.g. during sleeping). }\end{array}$ & $\begin{array}{l}\text { Animals need food to } \\
\text { grow; growing takes place } \\
\text { only at particular times } \\
\text { (e.g. during sleeping). }\end{array}$ & $\begin{array}{l}\text { Animals need food to grow which } \\
\text { makes them stretch or get bigger; } \\
\text { growing takes place only at } \\
\text { particular times (e.g. during } \\
\text { sleeping). }\end{array}$ \\
\hline Why do we eat? & $\begin{array}{l}\text { To stay alive, keep } \\
\text { healthy, to grow. }\end{array}$ & $\begin{array}{l}\text { To stay alive, keep } \\
\text { healthy, to grow. }\end{array}$ & $\begin{array}{l}\text { To stay alive, keep healthy, to } \\
\text { grow. }\end{array}$ \\
\hline $\begin{array}{l}\text { Anatomical location } \\
\text { of the stomach }\end{array}$ & $\begin{array}{l}\text { Circular organ in the } \\
\text { abdomen, about the level } \\
\text { of the navel. }\end{array}$ & $\begin{array}{l}\text { Circular organ in the } \\
\text { abdomen, about the level } \\
\text { of the navel; a tube } \\
\text { connects the mouth to } \\
\text { the stomach. }\end{array}$ & $\begin{array}{l}\text { Circular organ in the abdomen, } \\
\text { about the level of the navel; a tube } \\
\text { connects the mouth to the } \\
\text { stomach. }\end{array}$ \\
\hline $\begin{array}{l}\text { The fate of ingested } \\
\text { food }\end{array}$ & $\begin{array}{l}\text { Food goes to the stomach } \\
\text { and remains there } \\
\text { unchanged (or) food } \\
\text { enters the body cavity } \\
\text { and ends up unchanged } \\
\text { throughout the body, } \\
\text { including at the ends of }\end{array}$ & $\begin{array}{l}\text { Food goes to the stomach } \\
\text { (poor understanding of } \\
\text { the fate of food beyond } \\
\text { the stomach); the body } \\
\text { breaks food down into } \\
\text { smaller pieces to help } \\
\text { extract nourishment; }\end{array}$ & $\begin{array}{l}\text { Food goes to the stomach (poor } \\
\text { understanding of the fate of food } \\
\text { beyond the stomach); the body } \\
\text { breaks food down into smaller } \\
\text { pieces to help extract nourishment; } \\
\text { solids and liquids take separate } \\
\text { pathways through the body. }\end{array}$ \\
\hline
\end{tabular}

Figure 1. Continued. 


\begin{tabular}{|c|c|c|c|}
\hline & $\begin{array}{l}\text { arms and legs (hollow bag } \\
\text { model); solids and liquids } \\
\text { take separate pathways } \\
\text { through the body. }\end{array}$ & $\begin{array}{l}\text { solids and liquids take } \\
\text { separate pathways } \\
\text { through the body. }\end{array}$ & $\begin{array}{l}\text { Starts to think about the digestive } \\
\text { system as a differentiated tube of } \\
\text { different organs. }\end{array}$ \\
\hline Egestion of food & $\begin{array}{l}\text { All ingested food leaves } \\
\text { the body through the } \\
\text { bottom (or) faeces is not } \\
\text { related to digestion at all. }\end{array}$ & $\begin{array}{l}\text { Some food leaves the } \\
\text { body through the } \\
\text { bottom, the rest is kept } \\
\text { inside the body. }\end{array}$ & $\begin{array}{l}\text { Some food leaves the body through } \\
\text { the bottom, the rest is kept inside, } \\
\text { being sent around the body in the } \\
\text { blood. }\end{array}$ \\
\hline Skeleton & $\begin{array}{l}\text { Bones are often } \\
\text { dumbbell-shaped. }\end{array}$ & $\begin{array}{l}\text { Bones are often } \\
\text { dumbbell-shaped; they } \\
\text { support the rest of the } \\
\text { body; they are not living } \\
\text { tissue. }\end{array}$ & $\begin{array}{l}\text { Bones are often dumbbell-shaped; } \\
\text { they support the rest of the body; } \\
\text { they are living tissue because they } \\
\text { grow and can repair themselves. }\end{array}$ \\
\hline Muscular system & $\begin{array}{l}\text { Muscles are located } \\
\text { exclusively in the arms } \\
\text { and legs. }\end{array}$ & $\begin{array}{l}\text { Muscles are located } \\
\text { exclusively in the arms } \\
\text { and legs. }\end{array}$ & $\begin{array}{l}\text { Muscles are located exclusively in } \\
\text { the arms and legs. } \\
\text { Starts to link muscles with } \\
\text { movement. }\end{array}$ \\
\hline $\begin{array}{l}\text { Location of the } \\
\text { heart }\end{array}$ & $\begin{array}{l}\text { Drawn as a 'valentine' } \\
\text { shape in the abdomen. }\end{array}$ & $\begin{array}{l}\text { Drawn as a 'valentine' } \\
\text { shape in the left side of } \\
\text { the chest. }\end{array}$ & $\begin{array}{l}\text { Drawn as a 'valentine' shape in the } \\
\text { left side of the chest. }\end{array}$ \\
\hline Blood circulation & $\begin{array}{l}\text { The heart beats; blood is } \\
\text { a red liquid that keeps } \\
\text { you alive; blood splashes } \\
\text { around freely inside the } \\
\text { body and is not contained } \\
\text { by blood vessels; poor } \\
\text { understanding of the } \\
\text { double circulation. }\end{array}$ & $\begin{array}{l}\text { The heart beats; it pumps } \\
\text { blood around the body; } \\
\text { blood is a red liquid that } \\
\text { keeps you alive; blood is } \\
\text { found in veins; poor } \\
\text { understanding of the } \\
\text { double circulation. }\end{array}$ & $\begin{array}{l}\text { The heart beats; it pumps blood } \\
\text { around the body; blood is a red } \\
\text { liquid that keeps you alive; blood is } \\
\text { found in veins; poor understanding } \\
\text { of the double circulation. } \\
\text { Starts to appreciate that the blood } \\
\text { is a transport system that carries } \\
\text { different substances around the } \\
\text { body. }\end{array}$ \\
\hline Respiratory system. & $\begin{array}{l}\text { Lungs are unknown; the } \\
\text { stomach or abdomen is } \\
\text { responsible for breathing } \\
\text { (or) air is breathed in, } \\
\text { circulates freely inside } \\
\text { the head (or inside an } \\
\text { empty body), and then } \\
\text { breathed out. }\end{array}$ & $\begin{array}{l}\text { There are two lungs that } \\
\text { connect with the mouth } \\
\text { by a tube; actual position } \\
\text { of the lungs is not well } \\
\text { known (sometimes } \\
\text { placed in the abdomen). }\end{array}$ & $\begin{array}{l}\text { There are two lungs that connect } \\
\text { with the mouth by a tube; actual } \\
\text { position of the lungs is not well } \\
\text { known (sometimes placed in the } \\
\text { abdomen); lungs help give oxygen } \\
\text { to the blood (or) air enters the } \\
\text { lungs then passes directly to the } \\
\text { heart via tubes. }\end{array}$ \\
\hline
\end{tabular}

\section{Research examples supporting learning progression}

It is currently difficult to produce learning progression for ages less than five years due to a lack of substantive science conceptual research, and as noted earlier, the studies into preschoolers' science concepts that are available tend not to describe how ideas change over time. In the final section of this paper, we present exemplars of our own research that may go some way towards correcting this imbalance. The first study looked at 3-5-year-old's ideas of animal classification, asking them to categorise plastic models of animals into the sets fish, amphibians, reptiles, birds, mammalsand insects(Allen, 2015). We also asked the children the reasons for their choices in order to determine set criteria. The fis $h$ data yielded interesting 
results. At three years, children tended to correctly place models of angelfish and clownfish into the fish category, basing their choices solely on physical attributes such as the model has fins and a tail and looks 'fish-like'. In contrast, the five-year-olds incorrectly decided other models were fish such as the crab, jellyfish, starfish and octopus. This was notable since it represented a decline in scientific knowledge with age; that is to say, the three-year-olds outperformed the five-year-olds, largely because the older children thought that any animal that lived in the sea and was capable of swimming was a fish. Other research with pupils aged 5-16 years has shown that between the ages of 5 and 11, this same belief was also prevalent but then start to improve after 11 years because the incorrect species were starting to be omitted from pupils' fish sets, which constitutes U-shaped development of ideas over time (Figure 2).

Figure 2. U-shaped development of the fish concept over the ages 3-16 years.

\section{U shaped development}

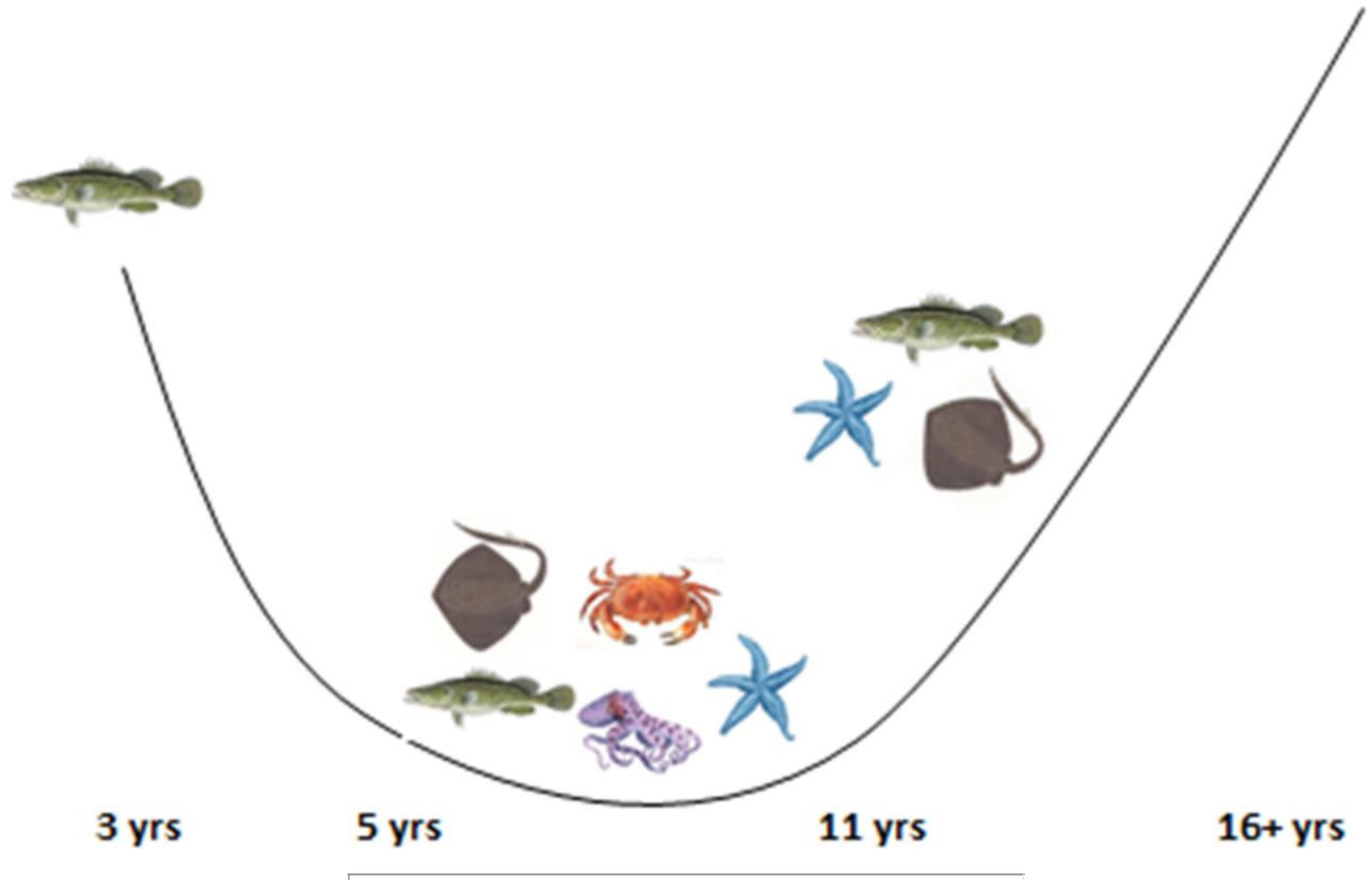

The second study examined the relationship between learning progression and teachers' awareness of children's misconceptions aiming to examine whether children's ideas are more successfully altered when teachers are aware of the learners' misconceptions (Kambouri, 2011[AQ171). To investigate this, an experimental case study was designed and two kindergarten classes (4-5-year-old children) participated. A lesson on 'Rain and the Water Cycle' was observed, while being delivered by the classroom's teacher, and three randomly selected children were interviewed before and after each lesson. The children were interviewed in groups, which encouraged their engagement and helped to identify their misconceptions in relation to the specific topic. The children's answers from the first group were shared with the classroom children, something that did not happen for the case of the second group. The results showed a considerable difference between the learning progression when comparing the two groups, since the responses collected during the post-interviews with the children from the first group, who provided more correct answers and expressed fewer misconceptions, indicated a greater development and progress in their understanding of the specific phenomenon. Based on this case study, it is more likely for children to overcome their misconceptions when teachers take their initial misconceptions into account as they plan and teach science lessons (Kambouri, 2011).

The last study looked at how 3-5-year-olds think about the kinds of food that animals eat (Allen, in preparation). We presented children with a series of simple three-step food chains, including grass $\rightarrow$ rabbit $\rightarrow$ fox and grass $\rightarrow$ zebra $\rightarrow$ lion. Children then chose which animal in each food chain was the predator, which was the prey, and whether any of the animals were herbivores and would eat the plant. The older children were more able to correctly identify predator, prey and herbivore, and also correctly recognise that the reason why the predator chased the prey was because it wanted to eat it - in contrast, the younger children tended not to know what happened next after the predator had caught the prey. Only as more studies are completed that characterise how preschoolers' concepts change over time will we be able to construct learning progressions that can be of use to early years practitioners and inform their delivery of relevant, science material.

\section{Concluding comments}

The lack of studies of science conceptual development at the preschool level presents a golden opportunity for researchers to lay down firm foundations for how learning progressions originate in children's early thinking. These findings would link together with the body of work that has shown how older children's scientific ideas develop during the primary years, providing, ideally, a seamless continuum that both early years practitioners and primary teachers could utilise to plan and deliver lessons based on common theory. Evidentially sourced teaching is coming increasingly to the fore in England, which can only facilitate these processes, encouraging and inspiring researchers, and hopefully teachers themselves, to take teaching forward into the twenty-first century and help transform the profession into one which is strongly guided by and a generator of usable, valid 


\section{Disclosure statement}

No potential conflict of interest was reported by the authors[AQ19].

\section{References}

Allen, M. (2014). Misconceptions in primary science (2nd ed.). Maidenhead: McGraw-Hill.[AQ20]

Allen, M. (2015). Preschool children's taxonomic knowledge of animal species. Journal of Research in Science Teaching, 52(1), 107-134.

Allen, M. (2016). The best ways to teach primary science: Research into practice. Maidenhead: Open University Press.

Allen, M. (in preparation). 'Can zebras hunt lions?' Early understandings of food chain triads.[AQ21]

Atherton, J.S. (2009). Learning and teaching:Piaget's developmental theory. Retrieved December 21, 2010, from http://www.learningandteaching.info/learning/piaget.htm.

Au, T. K. F. (1994). Developing an intuitive understanding of substance kinds. Cognitive Psychology, 27(1), 71-111.

Bradley, L. S. (1996). Children learning science. Oxford: Nash Pollack.

Bruner, J., Goodnow, J. J., \& Austin, G. A. (1967). A study of thinking. New York, NY: Science Editions.

Daniel, H. (2002). Vygotsky and pedagogy. New York, NY: RoutledgeFalmer.

De Kock, J. (2005). Science in early childhood. ASE Papers, (16), 117-126.[AQ22]

Department for Education. (2013). Science programmes of study: Key stages 1 and 2. London: Crown Copyright.

Doherty, J., \& Hughes, M. (2009). Child development theory and practice 0-11. Essex: Pearson.

Doidge, N. (2007). The brain that changes itself: Stories of personal triumph from the frontiers of brain science. NewYork, NY: Penguin Group.

Driver, R., Asoko, H., Leach, J., Mortimer, E., \& Scott, P. (1994). Constructing scientific knowledge in the classroom. American Educational Research Association, 23(7), 5-12.

Eaton, J. F., Anderson, C. W., \& Smith, E. L. (1984). Student's misconceptions interfere with science learning: Case studies of fifth-grade students. The Elementary School Journal, 84(4), 365-379.

Eliot, L. (1999). What's going on in there? How the brain and mind develop in the first five years of life. New York, NY: Bantam Books (Random House).

Gallegos-Cázares, L., Flores-Camacho, F., \& Calderón-Canales, E. (2009). Preschool science learning: The construction of representations and explanations about color, shadows, light and images. Review of Science, Mathematics and ICT Education, 3(1), 49-73.

Gelman, R. (1990). First principles organize attention to and learning about relevant data: Number and the animate-inanimate distinction as examples. Cognitive Science, 14(1), 79-106.

Harlen, W. (2010). Principles and big ideas of science education. Great Britain: Ashford Colour Press.

Hollins, M., Whitby, V., Lander, L., Parson, B., \& Williams, M. (2001). Progression in primary science: A guide to the nature and practice of science in key stage 1 and 2. London: David Fulton.

Jahoda, G. (1983). European 'lag' in the development of an economic concept: A study in Zimbabwe. British Journal of Developmental Psychology, 1, 113-120.

Johnston, J. (2005). Early explorations in science. Maidenhead: Open University Press.

Kalish, C.W.(1996). Preschoolers' understanding of germs as invisible mechanisms. Cognitive Development, 11(1), 83-106.

Kambouri, M. (2015). Investigating early years teachers' understanding and response to children's preconceptions. European Early Childhood Education Research Journal, 25.[AQ25]

Kuhn, T. S. (1962). The structure of scientific revolutions. Chicago, IL: The University of Chicago Press. 
National Research Council. (2012). A framework for K-12 science education: Practices, crosscutting concepts, and core ideas. Committee on a Conceptual Framework for New.

Nussbaum, J. (1989). Classroom conceptual change: Philosophical perspectives. International Journal of Science Education, 11(5), 530-540.

Palmer, J. A. (1995). Environmental thinking in the early years: Understanding and misunderstanding of concepts related to waste management. Environmental Education Research, 1(1), 35-45.

Piaget, J. (1972). The psychology of the child. New York, NY: Basic Books.

Piaget, J. (1977). The development of thought: Equilibration of cognitive structures. Oxford: Basil Blackwell.

Plummer, J. D., \& Krajcik, J. (2010). Building a learning progression for celestial motion: Elementary levels from an earthbased perspective. Journal of Research in Science Teaching, 47(7), 768-787.

Posner, G., Strike, K., Hewson, P., \& Gertzog, W. (1982). Accommodation of a scientific conception: Towards a theory of conceptual change. Science Education, 66, 211-227.

Ravanis, K., \& Bagakis, G. (1998). Science education in kindergarten: Sociocognitive perspective. International Journal of Early Years Education, 6(3), 315-327.

Saçkes, M., Flevares, L. M., \& Trundle, K. C. (2010). Four to six-year-old children's conceptions of the mechanism of rainfall. Early Childhood Research Quarterly, 25, 536-546.

Smidt, S. (2009). Introducing Vygotsky. A guide for practitioners and students in early years education. Oxon: Routledge.

Springer, K. (1992). Children's awareness of the biological implications of kinship. Child Development, 63(4), 950-959.

Stepans, J., \& Kuehn, C. (1995). Children's conceptions of weather. Science and Children, 23(1), 44-47.

Treagust, D. F. (1988). Development and use of diagnostic tests to evaluate students' misconceptions in science. International Journal of Science Education, 10(2), 159-169.

Valanides, N., Gritsi, F., Kampeza, M., \& Ravanis, K. (2000). Changing Pre-school Children's Conceptions of the Day/Night Cycle Changer les Conceptions d'Enfants d'Age Prescolaire sur le Phenomene du Cercle 'Jour-Nuit' Cambiar las Concepciones de los Ninos Preescolares en el Ciclo Dia/Noche. International Journal of Early Years Education, 8(1), 27-39.

Vygotsky, L. (1978). Mind and society. Cambridge, MA: Harvard University Press.

Vygotsky, L. S. (1986). Thought and language (Revised ed.).[AQ27]

Windt, A., Scheuer, R., \& Melle, I. (2014). Scientific experiments in early childhood education - different learning opportunities and implications in practice. Journal of Emergent Science, 7, 30-34.

Zull, J.E. (2002). The art of changing the brain: Enriching the practice of teaching by exploring the biology of learning. Sterling, VA: Stylus. 